Supporting Information

\title{
Vitamin E-Labeled Polyethylenimine for in vitro and in vivo Gene Delivery
}

Jinxing Liuł, Mengke Feng", Duanwei Liang, Jiali Yang, Xinjing Tang*

State Key Laboratory of Natural and Biomimetic Drugs and Beijing Key Laboratory

of Molecular Pharmaceutics and New Drug Delivery Systems, School of

Pharmaceutical Sciences, Peking University No. 38 Xueyuan Road Beijing, 100191, China 


\section{Synthesis of PEI-vitE conjugates}

Synthesis of vitE-OH. vitE-OH was synthesized via a simple substitution reaction between vitamin $E$ (vitE) and 2-bromoethanol according to the literature ${ }^{[1]}$ with minor modification. Briefly, vitE (5.0 g, $1.0 \mathrm{eq}), 2$-bromoethanol $(1.1 \mathrm{~mL}, 1.25 \mathrm{eq})$ and $\mathrm{NaOH}(0.7$ $\mathrm{g}, 1.5 \mathrm{eq}$ ) were mixed in $25 \mathrm{~mL}$ anhydrous $\mathrm{DMF}$, and stirred at $90^{\circ} \mathrm{C}$ overnight. The mixture was cooled to room temperature, then poured into water $(100 \mathrm{~mL})$. The solution was extracted with methyl tert-butyl ether $(50 \mathrm{~mL} \times 3)$. The organic layers were combined and evaporated in vacuum to leave the residue that was further purified by silica gel column chromatography using a mixture of petroleum ether (PE) and ethyl acetate (EA) as eluent (PE:EA = 5:1). Yield: $4.5 \mathrm{~g}(81.7 \%) .{ }^{1} \mathrm{H} \mathrm{NMR}\left(\delta / \mathrm{ppm}, 400 \mathrm{MHz}, \mathrm{CDCl}_{3}\right)$ 4.04-3.93 (t, $2 \mathrm{H}, \mathrm{OCH}_{2} \mathrm{CH}_{2} \mathrm{OH}$ ), 3.85-3.80 (t, 2H, OCH $\mathrm{CH}_{2} \mathrm{OH}$ ), 2.61 (t, J = 6.7 Hz, 2H, $\mathrm{PhCH}_{2} \mathrm{CH}_{2}$ ), 2.35 (brs, $1 \mathrm{H}, \mathrm{OH}$ ), 2.22 (s, 3H, $\mathrm{CH}_{3}$ ), 2.18 (s, 3H, $\left.\mathrm{CH}_{3}\right), 2.13\left(\mathrm{~s}, 3 \mathrm{H}, \mathrm{CH}_{3}\right)$, $1.80\left(\mathrm{~m}, 2 \mathrm{H}, \mathrm{PhCH}_{2} \mathrm{CH}_{2}\right), 1.68-1.02(\mathrm{~m}, 24 \mathrm{H}), 1.00-0.80\left(\mathrm{~m}, 12 \mathrm{H}, 4 \times \mathrm{CH}_{3}\right) .{ }^{13} \mathrm{C} \mathrm{NMR}$ (ס/ppm, $\left.101 \mathrm{MHz}, \mathrm{CDCl}_{3}\right)$ : 147.99, 147.63, 127.72, 125.74, 123.00, 117.63, 74.86, 73.71, $67.99,62.43,40.11,39.40,37.44,32.76,31.24,28.01,25.63,24.84,24.47,23.89,22.70$, 21.07, 20.67, 19.69, 12.74, 11.84. MS: calculated: 474.41, found: 474.69 [M] $]^{+}, 497.64$ [M $+\mathrm{Na}]^{+}$.

Synthesis of vitE-COOH. vitE-COOH was synthesized by coupling adipic acid to vitE-OH through carbodiimide chemistry. Briefly, DCC (2.6 g, 2.0 eq), DMAP (8.0 mg, 0.1 eq) were added to a solution of vitE-OH $(3.0 \mathrm{~g}, 1.0 \mathrm{eq})$ and adipic acid $(2.8 \mathrm{~g}, 3.0 \mathrm{eq})$ in $45 \mathrm{~mL}$ anhydrous THF at 0 to $5^{\circ} \mathrm{C}$, and stirred at room temperature for $6 \mathrm{~h}$. The white precipitate was filtered and the filtrate was evaporated in vacuum. The residue was dissolved in EA $(90 \mathrm{~mL})$, washed by water $(50 \mathrm{~mL} \times 2)$. The organic layers were dried over anhydrous $\mathrm{Na}_{2} \mathrm{SO}_{4}$. After filtration and evaporation in vacuum, the residue was purified by silica gel column chromatography using a mixture of dichloromethane (DCM) and methanol $(\mathrm{MeOH})$ as eluent (DCM:MeOH = 200:1, 0.5\% AcOH). Yield: $2.6 \mathrm{~g}(68.3 \%) .{ }^{1} \mathrm{H} \mathrm{NMR}$ (ס/ppm, 400 $\mathrm{MHz}, \mathrm{CDCl}_{3}$ ) 4.51-4.36 (t, 2H, OCH $\mathrm{CH}_{2} \mathrm{OH}$ ), 3.97-3.83 (t, 2H, OCH $\mathrm{CH}_{2} \mathrm{OH}$ ), 2.59 (t, J = 6.7 Hz, 2H, PhCH $2 \mathrm{CH}_{2}$ ), 2.53-2.36 (m, 4H, $\mathrm{COCH}_{2} \mathrm{CH}_{2}$ ), 2.20 (s, 3H, $\left.\mathrm{CH}_{3}\right), 2.16(\mathrm{~s}, 3 \mathrm{H}$, 
$\left.\mathrm{CH}_{3}\right), 2.11\left(\mathrm{~s}, 3 \mathrm{H}, \mathrm{CH}_{3}\right), 1.89-1.01(\mathrm{~m}, 28 \mathrm{H}), 0.97-0.78\left(\mathrm{~m}, 12 \mathrm{H}, 4 \times \mathrm{CH}_{3}\right) .{ }^{13} \mathrm{C} \mathrm{NMR}$ (ס/ppm, $\left.101 \mathrm{MHz}, \mathrm{CDCl}_{3}\right): 179.06,173.32,148.01,147.65,127.71,125.75,122.98$, $117.62,74.86,70.47,63.76,40.09,39.39,37.44,33.83,33.61,32.75,31.26,28.00,24.82$, $24.46,24.18,23.86,22.70,21.05,20.65,19.69,12.65,11.78 . ~ M S:$ calculated: 602.45 , found: $601.80[\mathrm{M}-\mathrm{H}]^{-}$.

Synthesis of PEI-vitE $n$. The PEI-vitE $n(n=2,4$ and 6$)$ conjugates were synthesized from $1.8 \mathrm{kDa} \mathrm{PEI}$ and vitE-COOH. The number of vitE modification per PEI was controlled by the feed ratio of vitE-COOH:PEI. Briefly, as shown in Table S1, vitE-COOH in anhydrous DCM (PEl-vitE $2: 3.0 \mathrm{~mL}$; PEl-vitE 4 : 3.75 mL; PEl-vitE 6 : $4.5 \mathrm{~mL}$ ) and TEA was activated with $\mathrm{CDI}$ for $1.5 \mathrm{~h}$ at room temperature, and the mixture was then added dropwise to a solution of $1.8 \mathrm{kDa} P E I$ in anhydrous DCM (PEl-vitE 2 : $13.4 \mathrm{~mL}$; PEl-vitE: $8.4 \mathrm{~mL}$; PEI-vitE 6 : $6.7 \mathrm{~mL}$ ). The solutions were stirred at room temperature for $3 \mathrm{~h}$ and evaporated in vacuum. The residues was then dissolved in distilled water $(10 \mathrm{~mL}, \mathrm{pH}$ adjusted to $8-9$ with $2 \mathrm{M} \mathrm{HCl}$ ) and purified by dialysis (MWCO $2000 \mathrm{Da}$ ) against distilled water for $24 \mathrm{~h}$. The dialysate was lyophilized to give the final products as $\mathrm{PEI}-\mathrm{vit} \mathrm{E}_{\mathrm{n}} \cdot \mathrm{xHCl}$, which were confirmed and analyzed by ${ }^{1} \mathrm{HNMR}, \mathrm{FTIR}$ and elemental analysis. Yield (PEI-vitE $2: 0.45 \mathrm{~g}$, 90.3\%; PEI-vitE 4 : 0.41 g, 93.9\%; PEl-vitE 6 : 0.44 g, 97.9\%). ${ }^{1} \mathrm{H}$ NMR (ס/ppm, 400 MHz, $\left.\mathrm{CD}_{3} \mathrm{OD}\right) 4.36\left(\mathrm{PhOCH}_{2} \mathrm{CH}_{2} \mathrm{O}\right), 3.79\left(\mathrm{PhOCH}_{2} \mathrm{CH}_{2} \mathrm{O}\right), \quad 3.21-2.63\left(\mathrm{CH}_{2} \mathrm{CH}_{2} \mathrm{NH}\right), \quad 2.57$ ( $\left.\mathrm{PhCH}_{2} \mathrm{CH}_{2}\right)$, 2.49-2.23 $\left(\mathrm{COCH}_{2} \mathrm{CH}_{2}\right)$, 2.21-1.94 $\left(\mathrm{PhCH}_{3}\right)$, 1.86-0.98 (characteristic peaks of vitE), $0.88\left(\mathrm{CH}_{3}\right)$.

Table S1. The feed ratio for the conjugation of vitE-COOH and PEl1.8. TEA, triethyl amine; CDI, carbonyldiimidazole; DCM, dichloromethane.

\begin{tabular}{|c|c|c|c|c|c|}
\hline $\mathrm{n}$ & vitE-COOH & TEA & CDI & PEI1.8 & DCM \\
\hline 2 & $0.20 \mathrm{~g}, 1.0 \mathrm{eq}$ & $0.14 \mathrm{~mL}, 3.0 \mathrm{eq}$ & $56.5 \mathrm{mg}, 1.05 \mathrm{eq}$ & $0.30 \mathrm{~g}, 0.5 \mathrm{eq}$ & $16 \mathrm{~mL}$ \\
\hline 4 & $0.25 \mathrm{~g}, 1.0 \mathrm{eq}$ & $0.17 \mathrm{~mL}, 3.0 \mathrm{eq}$ & $70.6 \mathrm{mg}, 1.05 \mathrm{eq}$ & $0.19 \mathrm{~g}, 0.25 \mathrm{eq}$ & $12 \mathrm{~mL}$ \\
\hline 6 & $0.30 \mathrm{~g}, 1.0 \mathrm{eq}$ & $0.21 \mathrm{~mL}, 3.0 \mathrm{eq}$ & $84.7 \mathrm{mg}, 1.05 \mathrm{eq}$ & $0.15 \mathrm{~g}, 0.17 \mathrm{eq}$ & $11 \mathrm{~mL}$ \\
\hline
\end{tabular}


FITC and TRITC labeling of PEI-vitE 6 and PEI25. PEI-vitE ${ }_{6}$ and PEI25 were labelled with fluorescein isothiocyanate (FITC, $\lambda_{\mathrm{ex}}=493 \mathrm{~nm}, \lambda_{\mathrm{em}}=525 \mathrm{~nm}$ ) or tetramethylrhodamine-5-(and-6)-isothiocyanate (TRITC, $\lambda_{\mathrm{ex}}=543 \mathrm{~nm}, \lambda_{\mathrm{em}}=571 \mathrm{~nm}$ ) for confocal laser scanning microscopy or in vivo imaging. For FITC labeling, 20 mg PEI-vitE 6 (or PEl25) was dissolved in $4 \mathrm{~mL}$ DMSO and stirred at room temperature. A solution of FITC in DMSO (5 mg/mL, $125 \mu \mathrm{L})$ was added dropwise into the polymer solution and stirred at $30^{\circ} \mathrm{C}$ for $4 \mathrm{~h}$. The obtained products were purified by dialysis (MWCO $2000 \mathrm{Da}$ ) against PBS for $24 \mathrm{~h}$. The dialysate was diluted to proper concentration for use (500 $\mathrm{ng} / \mu \mathrm{L})$. The procedure for TRITC labeling was the same as described above.

Determination of buffering capacity. The buffering capacity of PEI-vit $E_{n}$ conjugates and control PEls ( $1.8 \mathrm{kDa}$ and $25 \mathrm{kDa}$ ) was determined using acid-base titration assays with $\mathrm{pH}$ values of solutions ranging from 2.0 to 11.0 according to a previous report ${ }^{[2]}$ with minor modification. Briefly, a certain amount of modified and unmodified PEls $(0.2 \mathrm{mmol}$ of nitrogen atoms) was dissolved in $10 \mathrm{~mL} \mathrm{NaCl}$ solution $(150 \mathrm{mM})$. The PEI solutions were adjusted to a starting $\mathrm{pH}$ of 2.0 with $0.1 \mathrm{M} \mathrm{HCl}$, and were then titrated with $0.1 \mathrm{M} \mathrm{NaOH}$. The $\mathrm{pH}$ values of above solutions were monitored using a $\mathrm{pH}$ meter (Mettler Toledo FE20). For comparison, $150 \mathrm{mM} \mathrm{NaCl}$ was also titrated in the same way. The buffering capacity of these PEI conjugates and control PEls were calculated according to the following equation: Buffer Capacity $(\%)=100 \times\left(\Delta \mathrm{V}_{\mathrm{NaOH}} \times 0.1 \mathrm{M}\right) / \mathrm{N}$ mol, wherein $\Delta \mathrm{V}_{\mathrm{NaOH}}$ is the volume of $0.1 \mathrm{M} \mathrm{NaOH}$ solution that was required to adjust the $\mathrm{pH}$ value of $\mathrm{PEI}$ solutions from 5.1 to 7.4 , and $\mathrm{N} \mathrm{mol}$ is the total moles of amine groups that could be protonated in the tested PEls $(0.2 \mathrm{mmol})$.

\section{References}

1. W. Chen, S. K. Park, W. Yu, A. Xiong, B. G. Sanders, K. Kline, Eur. J. Med. Chem. 2012, 58, 72-83

2. M. Zheng, Y. Zhong, F. Meng, R. Peng, Z. Zhong, Mol. Pharmaceutics 2011, 8, 2434-2443 
Figure S1. Buffering capacity of PEI1.8, PEI25 and PEI-vitE $E_{n}$ by acid-base titration. 150 $\mathrm{mM} \mathrm{NaCl}$ was used as a control.

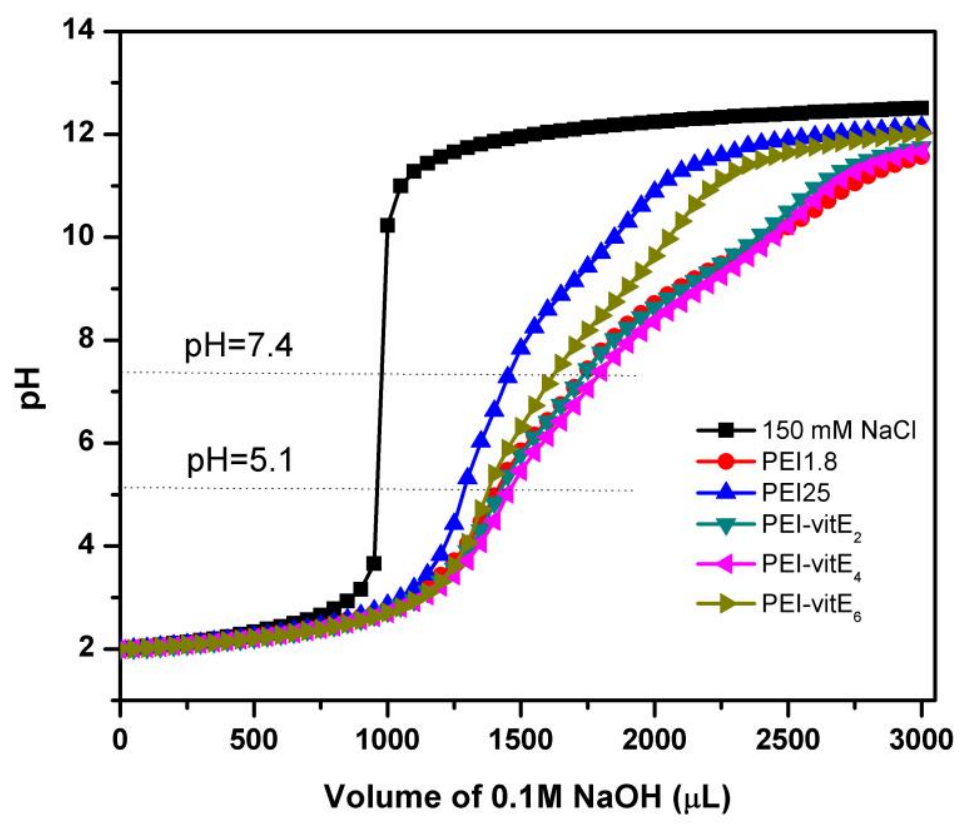

Figure S2. DNA protection by $\mathrm{PEl}-\mathrm{vitE}_{6}$ against DNase or serum. Lane 1: naked pDNA; Lane 2: $\mathrm{PEI}-\mathrm{vitE}_{6} / \mathrm{pDNA}(\mathrm{N} / \mathrm{P}=2)$; Lane 3: pDNA with DNase I or $10 \%$ serum for $2 \mathrm{~h}$; Lane 4: PEl-vitE $6 /$ pDNA with DNase I or $10 \%$ serum for $2 \mathrm{~h}$; Lane $5: \mathrm{PEI}-\mathrm{vitE}_{6} / \mathrm{pDNA}$ treated with heparin; Lane 6: PEI-vitE 6 /pDNA with DNase or $10 \%$ serum for $2 \mathrm{~h}$ followed by incubation at $65^{\circ} \mathrm{C}$ for $10 \mathrm{~min}$ to deactivate DNase and then treated with heparin.

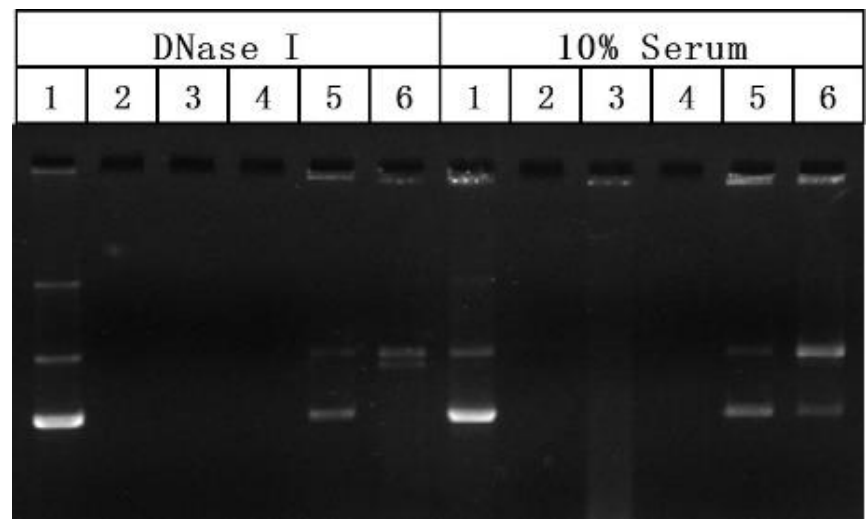


Figure S3. AFM images of $\mathrm{PEI}-\mathrm{vitE}_{6} / \mathrm{pDNA}$ complex at N/P ratio of 20. a) 3D topography image; b) 2D image; c) height image of the cross-section indicated by the white line in (b).

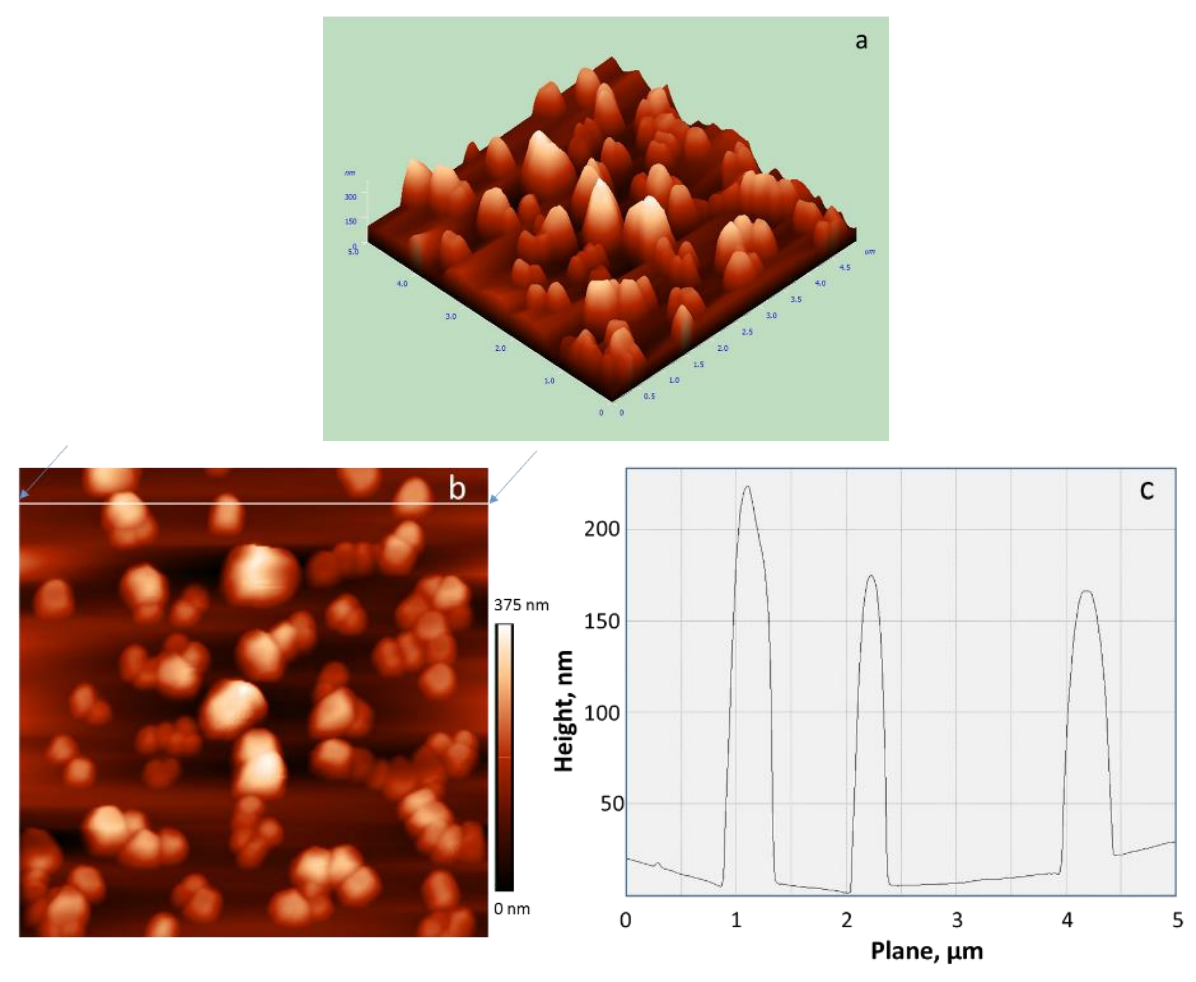

Figure S4. A) HEK-293A Cell viability at the presence of vitamin $E$ at various concentrations for $48 \mathrm{~h}$. B) HEK-293A Cell viability at the presence of PEI25, PEI1.8, and PEI-vitE $E_{n}(n=2,4,6)$ polymers at various concentrations for $48 \mathrm{~h}$, respectively. Data were expressed as mean \pm S.D.
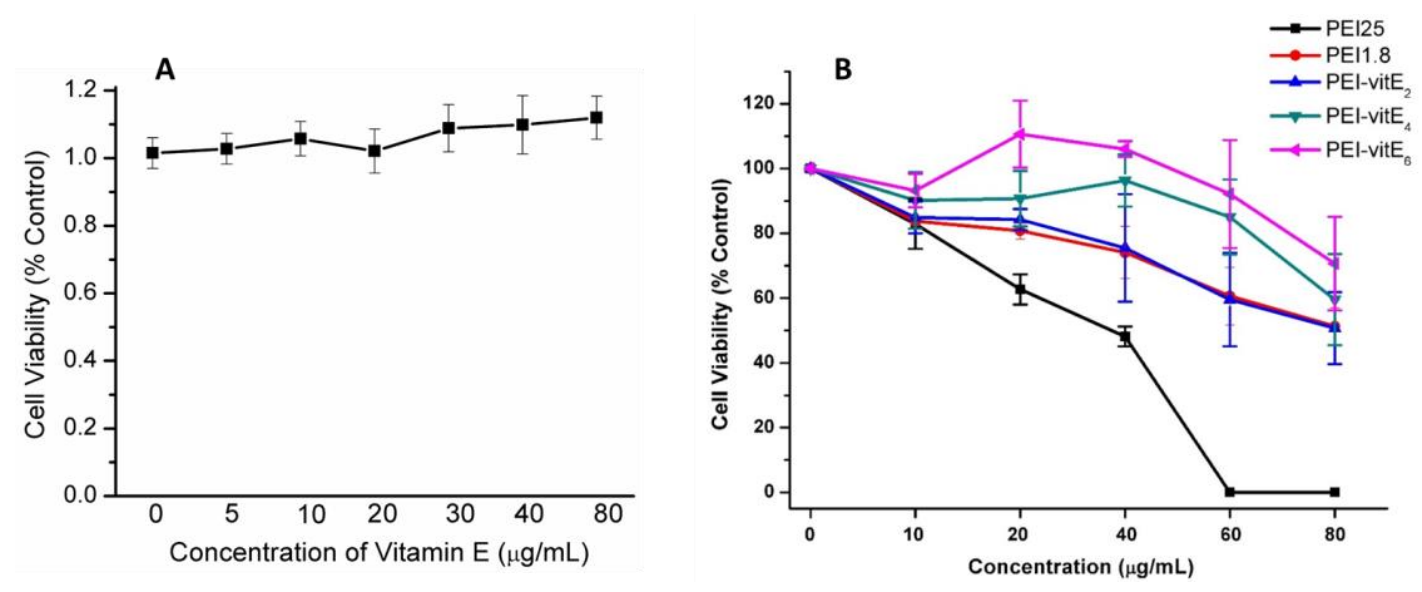
Figure S5. A) GFP gene expression imaged by High Content Screening System, scale bar is $200 \mu \mathrm{m}$. Gene transfection experiments of PEI-vitE $E_{6}$ at different N/P ratios were conducted, with Lipo $2000(2 \mu \mathrm{L})$ used as a control. B) GFP gene expression efficiency was evaluated by the number of GFP positive cells measured by flow cytometry.
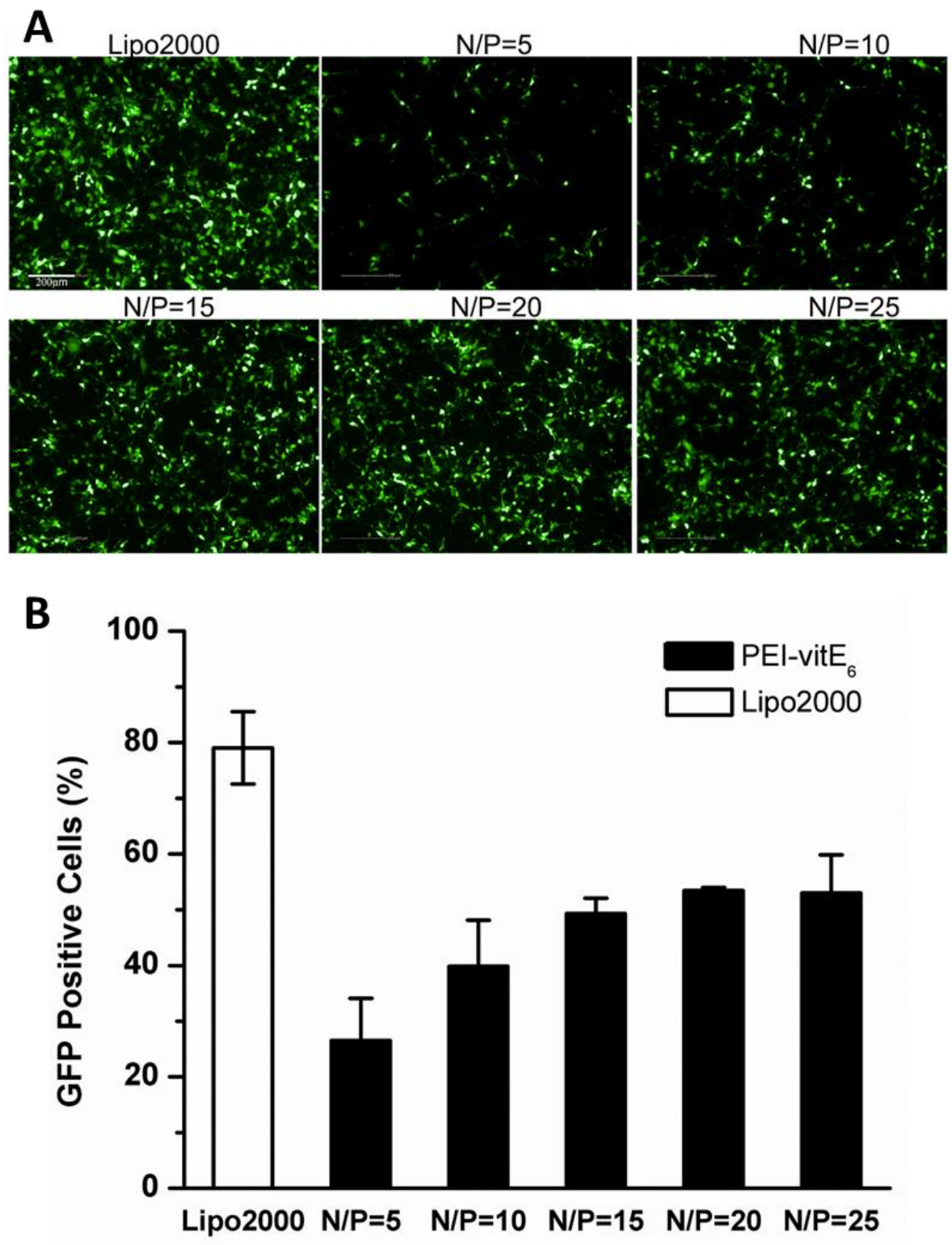
Figure S6. Uptake mechanism study of $\mathrm{PEI}-\mathrm{vit}_{6}$ by flow cytometry. Entrance inhibition of FITC-labelled $\mathrm{PEI}$-vitE 6 /pDNA complexes by four different endocytosis inhibitors as well as low temperature were investigated. PC stands for positive control without addition of inhibitors and incubated at $37^{\circ} \mathrm{C}$. Methyl- $\beta$-cyclodextrin $(M-\beta-C D, 16 \mu \mathrm{M})$, genistein (150 $\mathrm{nM})$, amiloride $(60 \mu \mathrm{M})$, chlorpromazine $(\mathrm{CPZ}, 15 \mu \mathrm{g} / \mathrm{mL})$ were chosen as inhibitors. The inhibition ratios were normalized by positive control.

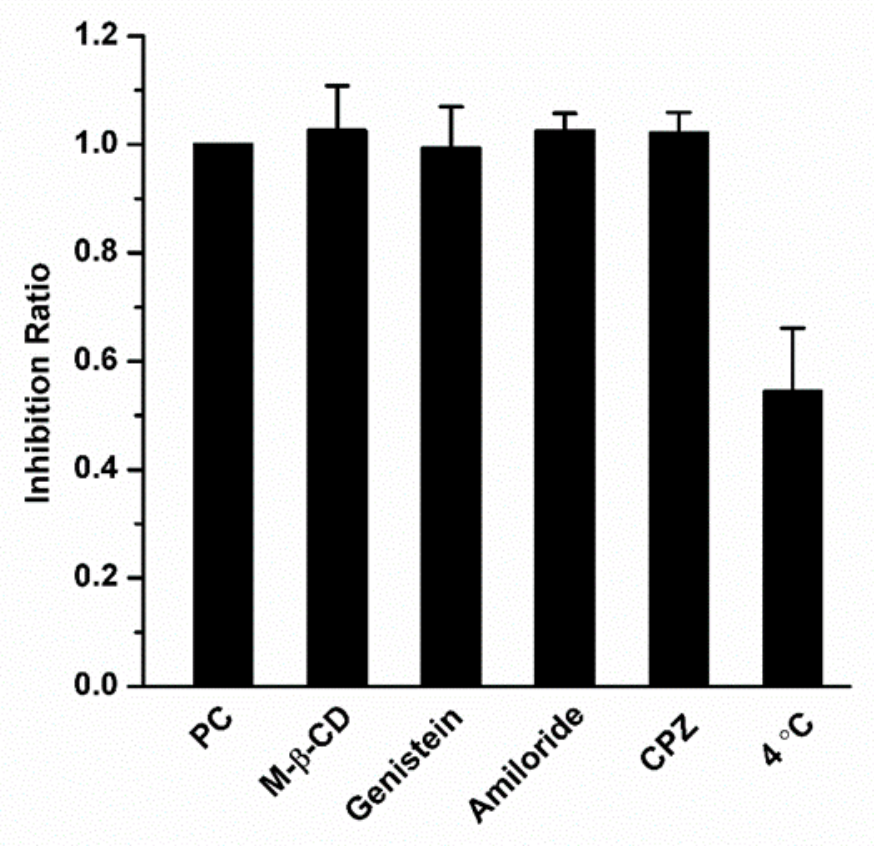

Figure S7. Competition experiments of vitE over FITC-labelled PEI-vitE $6 / p D N A$ complexes (A) and non FITC-labelled PEI25/pDNA complexes (B). HEK-293A cells were pre-incubated with vitE $(100 \mu \mathrm{M}, 200 \mu \mathrm{M}, 400 \mu \mathrm{M})$. Cells without vitE pre-incubation were used as positive control (PC) and the inhibition ratio was normalized over positive control.
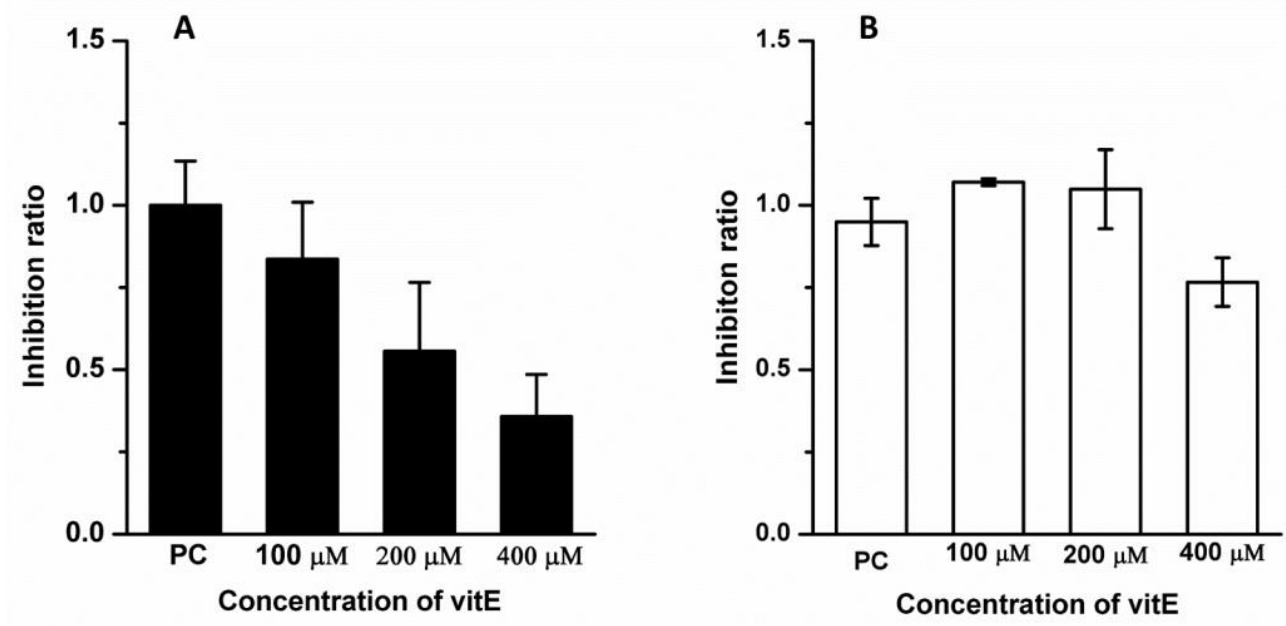
Figure S8. Body weight change of mice injected PEI25 or $\mathrm{PEI}_{-\mathrm{vitE}}$ for 40 days with PBS injection as control. The mice injected with PEI25 all died in $24 \mathrm{~h}$ post injection.

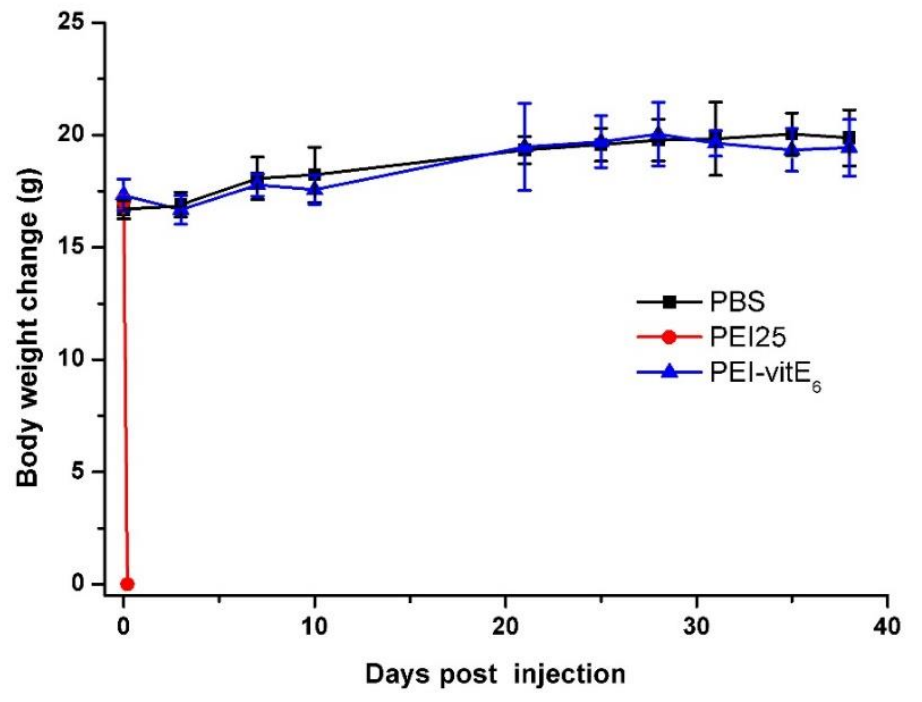

Figure S9. Distribution of TRITC-PEI-vitE 6 /pDNA in different organs over time. a) Control with no complexes injected; b) $0.5 \mathrm{~h}$ after complexes injected; c) $1 \mathrm{~h}$ after complexes injected; d) $2 \mathrm{~h}$ after complexes injected; e) $4 \mathrm{~h}$ after complexes injected.

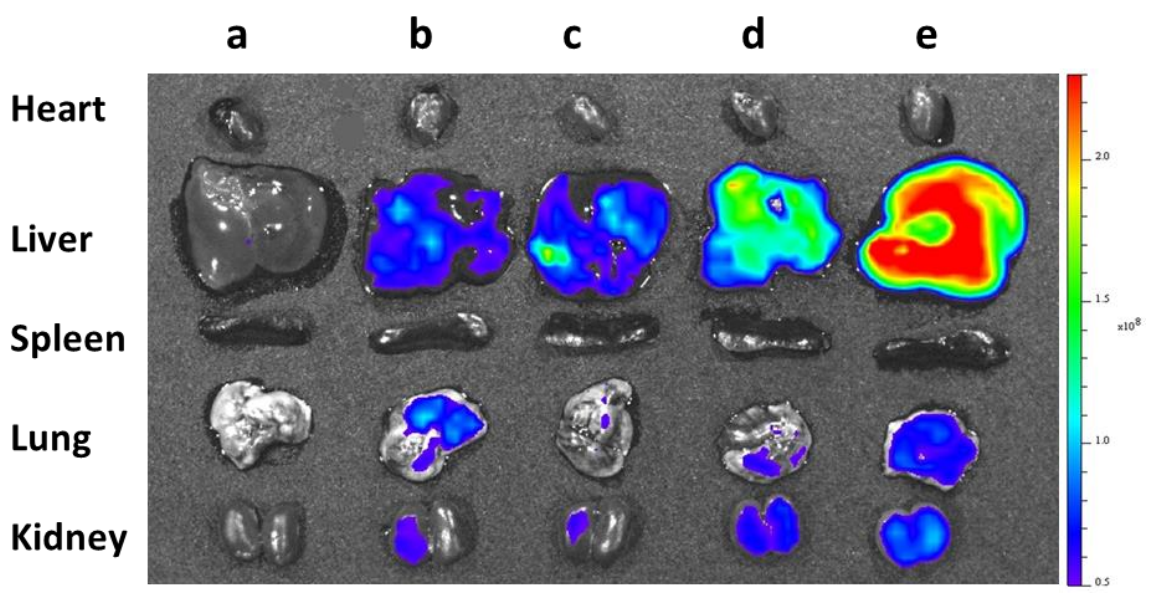


Figure S10. Fluorescence images for liver histology slices of mice injected with naked pDNA, PEI/pDNA, and PEI-vitE 6 /pDNA, respectively.

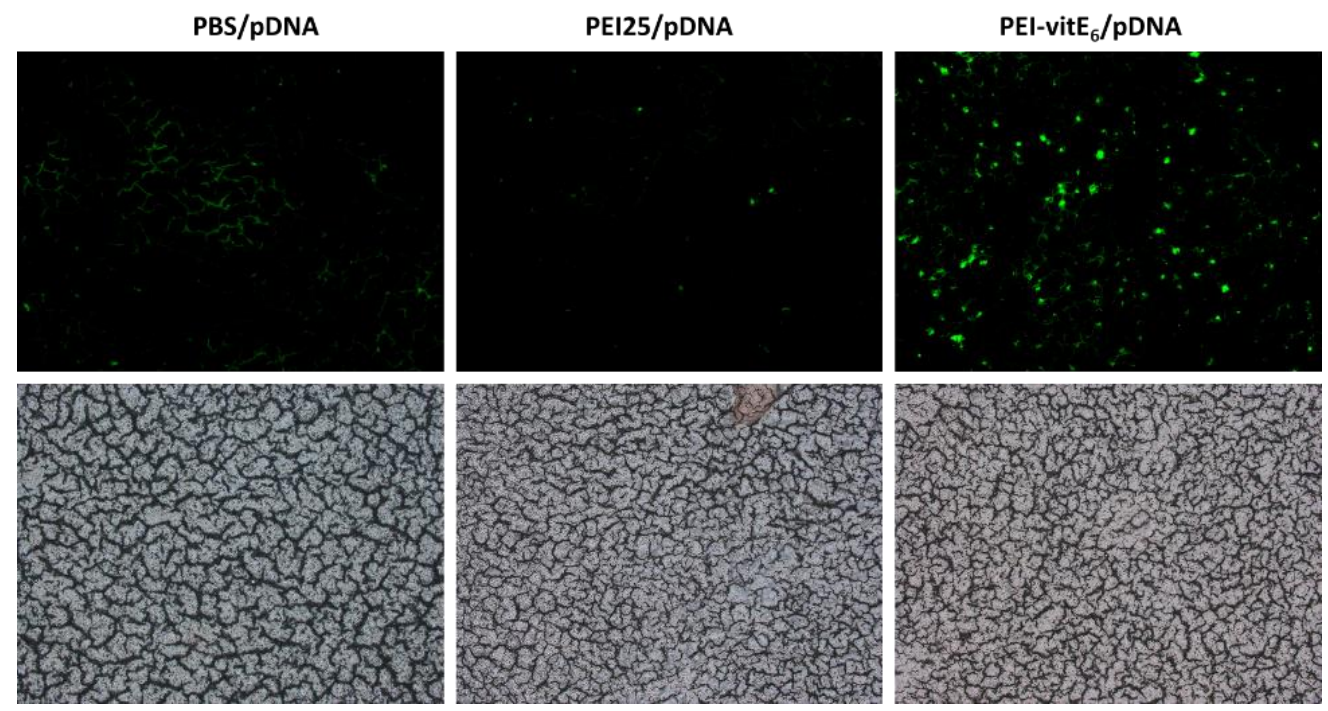


${ }^{1} \mathrm{H} \&{ }^{13} \mathrm{C}$ NMR spectra of intermediates
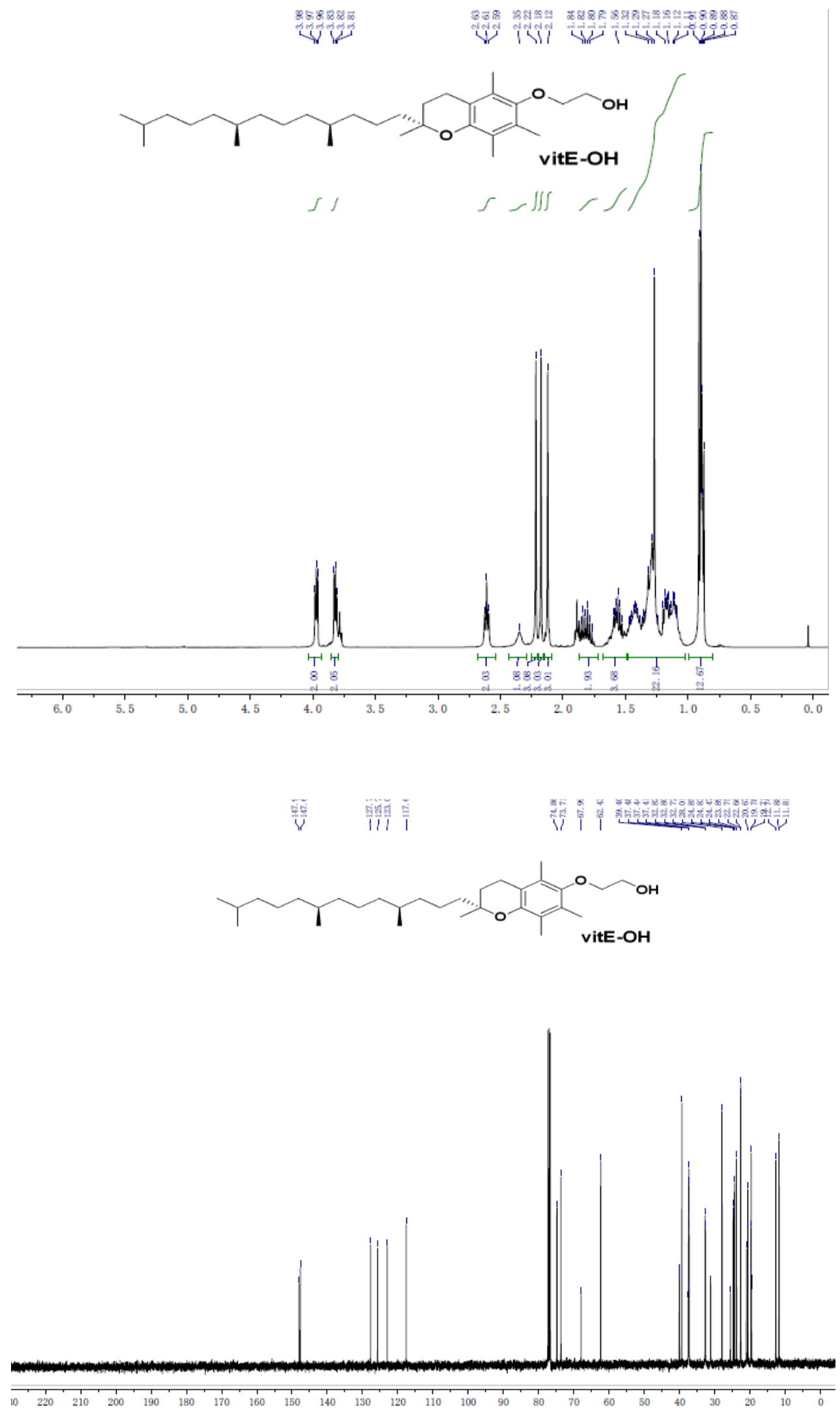

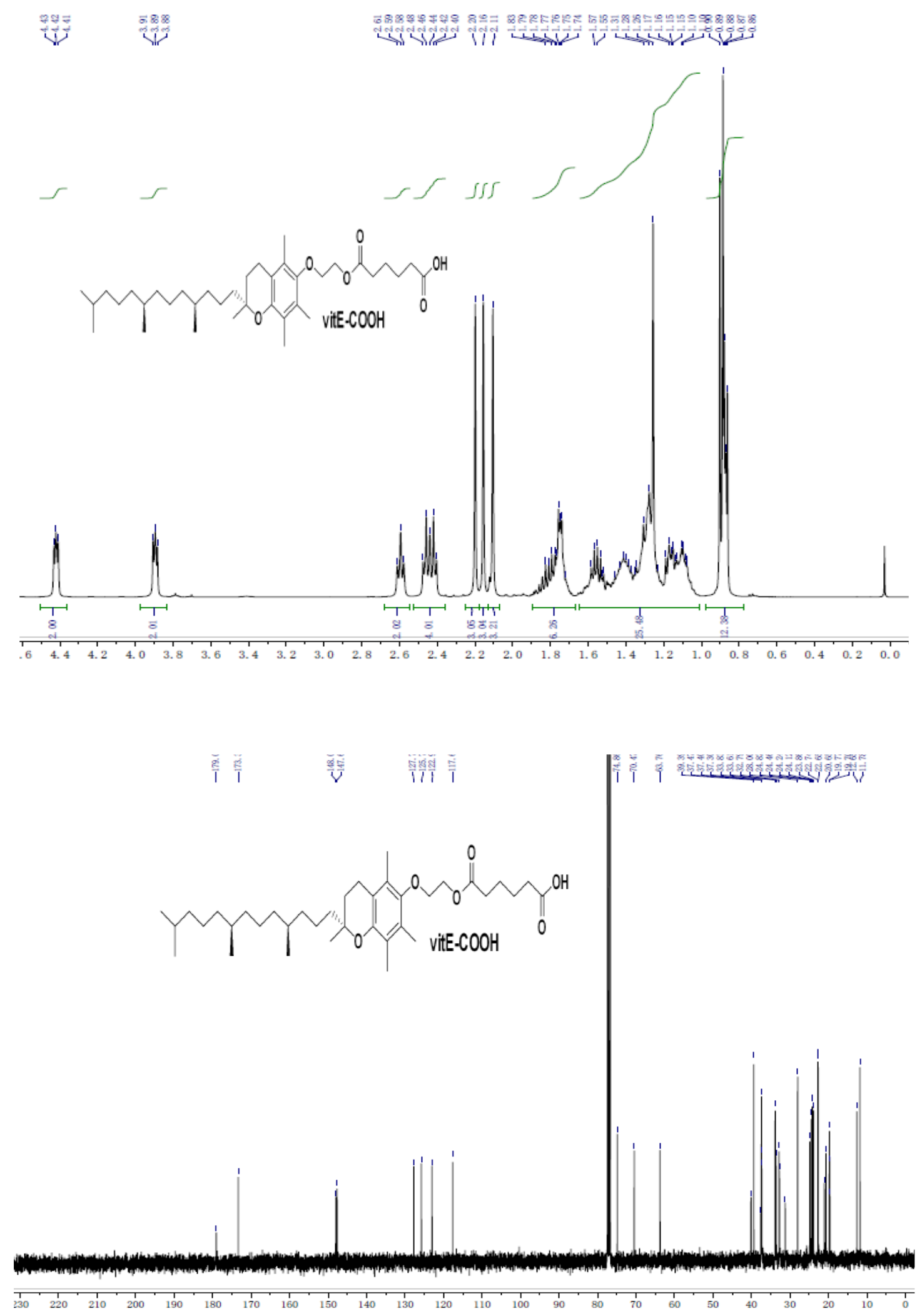


\section{Mass Spectrometry of intermediates}
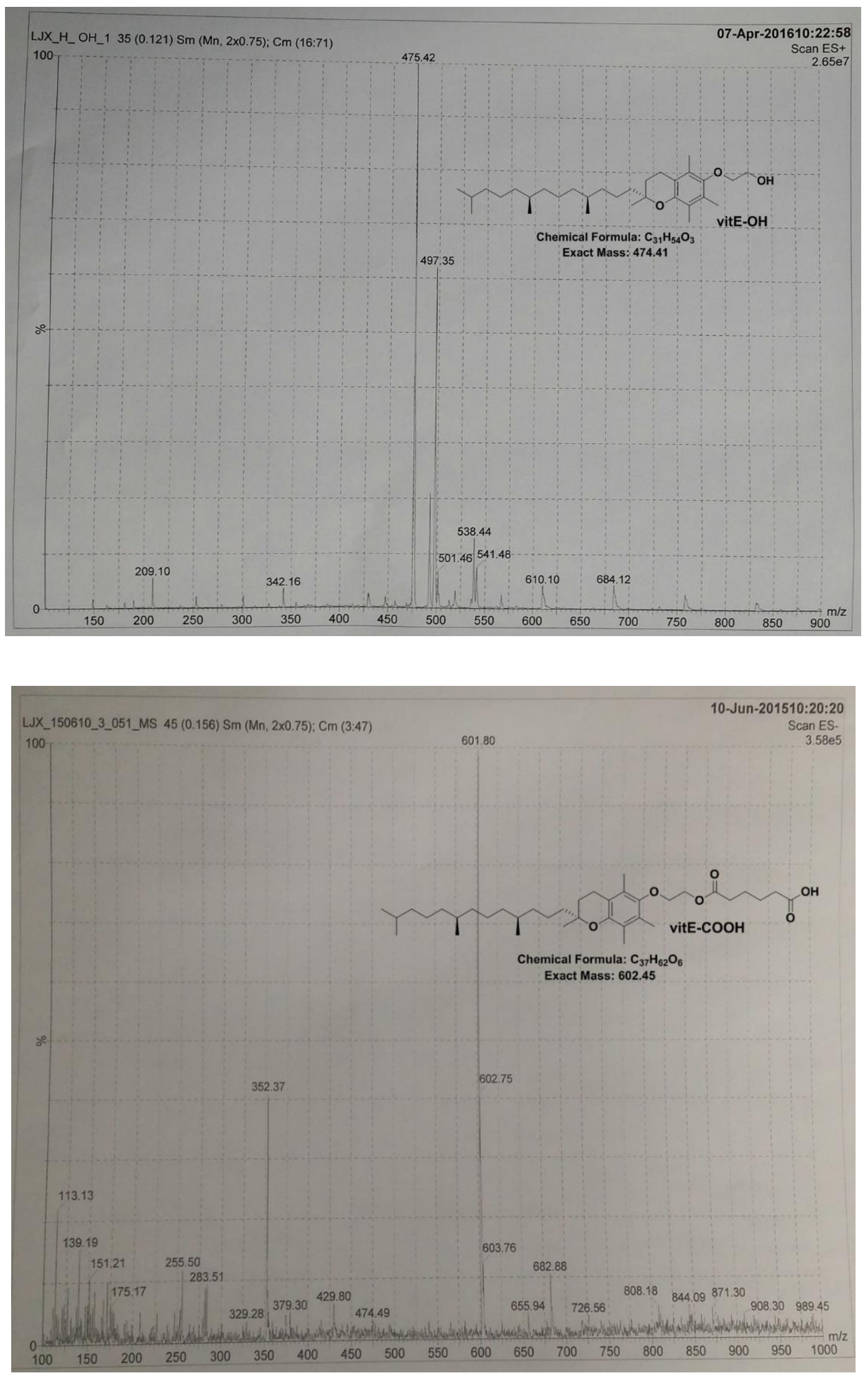